\title{
СУЧАСНІ МЕТОДИ ФІЗИЧНОЇ РЕАБІЛІТАЦІЇ ФУНКЦІї ХОДЬБИ ПІСЛЯ ГОСТРОГО ПОРУШЕННЯ МОЗКОВОГО КРОВООБІГУ
}

\author{
А. О. Голяченко, Я. Ю. Трофимчук \\ Тернопільський національний медичний університет \\ імені І. Я. Горбачевського МОЗ України
}

У роботі досліджено основні аспекти відновлення функції ходьби засобами фізичної терапії у хворих після перенесеного гострого порушення мозкового кровообігу. Включення в програму ранньої мобілізації хворих із гострим порушенням мозкового кровообігу методів кінезитерапії дозволяють говорити про значну ефективність запропонованої програми фізичної реабілітації порівняно зі загальноприйнятою програмою.

\section{MODERN METHODS OF PHYSICAL REHABILITATION OF GAIT FUNCTION AFTER ACUTE CEREBROVASCULAR ACCIDENT}

\author{
A. O. Golyachenko, Ya. Yu. Trofymchuk
}

\section{Horbachevsky Ternopil National Medical University}

The main aspects of restoration of walking function by means of physical therapy at patients after the transferred disturbance of cerebral circulation are investigated in the work. Inclusion in the program of early mobilization of patients with acute cerebrovascular disorders of kinesitherapy methods allow to speak about considerable efficiency of the offered program of physical rehabilitation in comparison with the generally accepted program.

Вступ. Судинна патологія мозку наполегливо заявляє про себе за сучасних умов життя з його прискореним темпом і високим нервовим напруженням. Найбільшу проблему становлять гіпертонічна хвороба та атеросклероз судин. Найтяжчим ускладненням цих захворювань $\epsilon$ інсульт, який у половині випадків уражає людей ще повних життєвих сил. Проте перспективи відновлення функцій і працездатності хворих залишаються досить обмеженими: після інфаркту міокарда до трудової діяльності повертаються близько 75-80 \% хворих, а після інсульту - лише 15-20 \% [3, 4, 6, 9].

Розробкою даної проблеми займалося багато науковців, представників різних галузей медичної науки: А. Н. Бєлова, С. М. Віничук, А. С. Кадиков, О. О. Копчак, О. К. Марченко, Л. Б. Новікова, С. Н. Попов, І. Л. Ревенько тощо. На даний час в Україні $\epsilon$ багато проектів щодо фізичної реабілітації пацієнтів з інсультами у гострий і ранній періоди реабілітації, створена Українська асоціація боротьби з інсультом.

Інсульт - це гостре порушення мозкового кровообігу, яке супроводжується структурно-морфологічними

(ㄷ.А.О. Голяченко, Я. Ю. Трофимчук, 2021 змінами у тканині мозку і стійким неврологічним дефіцитом, що утримується 24 год і більше після появи перших симптомів події. Його спричиняють дві основні патології, які реалізовуються двома різними шляхами, такими, як:

- блокування судини, відповідно певна ділянка не отримуватиме кисню;

- розрив судини, кров з якої ушкоджує частину мозку, яка має контакт із нею.

Усі ці процеси призводять до того, що страждає та функція, якою уражена частина мозку керувала.

Реабілітація після інсульту - це комплекс заходів (медикаментозних, психо-, фізіо- і кінезитерапевтичних), спрямованих на пом'якшення його наслідків, попередження ускладнень, тренування кардіореспіраторної системи й відновлення рухових функцій, мінімізацію ризику повторного інсульту, корекцію емоційних й когнітивних порушень, а також намагання домогтися повного відновлення працездатності пацієнта та його соціальної активності. На початковому етапі реабілітації враховується давність інсульту, вираження порушень, наявність супутніх захворю- 
вань (ішемічна хвороба серця, гіпертензія, діабет тощо), а також характер і перебіг основного судинного захворювання $[1,5,7,10]$.

На жаль, в даний час недостатньо кількості науково розроблених програм фізичної реабілітації хворих, які перенесли гостре порушення мозкового кровообігу у віддалений період інсульту. Приблизно у 60 \% хворих виникає порушення опорної та загалом рухової функцій внаслідок повного чи часткового геміпарезу чи геміплегії, що суттєво порушує функцію ходьби.

Рання мобілізація хворих із гострим порушенням мозкового кровообігу $є$ однією з головних засад фізичної терапії для успішного відновлення та профілактики повторних випадків інсульту [8]. Програми, здатні комплексно вирішувати відновлення фізичної, нейропсихічної й мовної сфери хворих, які перенесли гостре порушення мозкового кровообігу, саме в пізній період, відсутні [2].

Враховуючи вищевикладене, обрано тему нашого дослідження.

Мета роботи - дослідити основні аспекти відновлення функції ходьби засобами фізичної терапії у хворих після перенесеного гострого порушення мозкового кровообігу.

Методи дослідження: аналіз та узагальнення даних науково-методичної та спеціальної літератури; соціологічні методи (вивчення медичної документації, опитування), клінічні (соматоскопія, антропометрія, функціональні методи дослідження серцево-судинної системи), визначення ступеня тяжкості інсульту за шкалою інсульту, обстеження когнітивних функцій хворих на інсульт, оцінка активності повсякденної життєдіяльності за допомогою шкали Бартела, рівень участі - за допомогою тесту ходьби на 10 метрів, методи математичної статистики.

Основна частина. Дослідження проведено серед пацієнтів віком 40-70 років, яких поділено методом випадкової вибірки на дві групи: основну та контрольну.

У ході дослідження визначено функціональний стан осіб, хворих з ускладненнями ішемічного інсульту в пізній відновний період, і встановлено основні функціональні відхилення, які притаманні для даної категорії людей. Зокрема, відповідно до встановленого діагнозу, в хворих спостерігали геміпарез однієї половини тіла, порушення тонусу м'язів, рухові порушення верхньої та нижньої кінцівок, кисті та стопи, а також проблеми з самообслуговуванням.

Контрольна група займалася за класичною програмою реабілітації (медикаментозна терапія, дієтотерапія, ранкова гігієнічна гімнастика, лікувальна фізкультура, масаж), а хворі основної групи - додатково за розробленою нами програмою, яка, окрім класичних методів, містила дозовану ходьбу, заняття на тренажерах, фізіотерапію. Суть дослідження полягала в тому, щоб провести курс лікування післяінсультних хворих, застосовуючи запропонований нами метод, i порівняти його з результатами лікування аналогічних хворих контрольної групи, які проходили лікування за класичною методикою, та тим самим виявити ефективність застосованої нами методики лікувальної гімнастики.

У змінах функціонального стану осіб, які перенесли мозковий ішемічний інсульт, спостерігали тенденцію до покращення обстежуваних показників як в основній групі, так і в групі порівняння, проте у пацієнтів основної групи відбулися вірогідно $(p<0,05)$ більші зміни, ніж у пацієнтів групи порівняння за такими показниками:

- за шкалою інсульту, розробленою американським Національним інститутом здоров'я (NIH Stroke Skale), на початку дослідження в обох групах пацієнтів стан розцінювали як «неврологічні порушення легкого ступеня». Після проведеного дослідження в контрольній групі цей показник залишився без змін, а в основній відповідав рівню «задовільний»;

- за шкалою оцінки психічного стану (Mini-Mental State Examination) - стан когнітивних функцій на початку дослідження в обох групах дорівнював «деменції помірного ступеня». Після реабілітації в основній групі він відповідав «стадії переддементних когнітивних порушень», а в контрольній - «деменції легкого ступеня»;

- за шкалою Бартела (показник рухової активності) - на початку дослідження рівень рухової активності в основній та контрольній групах розцінювали як «помірну залежність», наприкінці дослідження залишився на первинному рівні. Проте встановлено, що покращення показника рухової активності за шкалою Бартела у пацієнтів основної групи становило 12,7 \%, а у хворих контрольної - тільки на 8,4 \%.

Висновки. 1. Рання мобілізація хворих із гострим порушенням мозкового кровообігу $є$ однією з головних засад фізичної терапії для успішного відновлення та профілактики повторних випадків інсульту.

2. Достовірна позитивна динаміка показників стану опорно-рухової та нервової системи в основній групі, порівняно з такими в контрольній групі, дозволяють говорити про значну ефективність запропонованої нами програми фізичної реабілітації порівняно із загальноприйнятою програмою.

42 ISSN 2411-1597. МЕДСЕСТРИНСТВО. 2021. № 1 


\section{СПИСОК ЛІТЕРАТУРИ}

1. Белова А. Н. Нейрореабилитация : руководство для врачей / А. Н. Белова. - 2-е изд., перераб. и дополн. - М. : Антидор, 2012. - 736 с.

2. Бодрова Р. А. Опыт применения международной классификации функционирования в оценке эффективности реабилитации пациентов с последствиями поражения ЦНС / Р. А. Бодрова, Э. И. Аухадеев, И. В. Тихонов // Практическая медицина. - 2013. - № 1 (66). - С. 98-100.

3. Виленский Б. С. Современное состояние проблемы инсульта / Б. С. Виленский, Н. Н. Яхно // Вестник Российской АМН. - 2008. - № 9-10. - С. 18-23.

4. Виленский Б. С. Инсульт - современное состояние проблемы / Б. С. Виленский // Неврологический журнал. 2008. - № 2. - С. 4-10.

5. Віничук С. М. Гострий ішемічний інсульт / С. М. Віничук, М. М. Прокопів. - К. : Наукова думка, 2008. - 286 с.

6. Волошин П. В. Аналіз поширеності та захворюваності на нервові хвороби в Україні / П. В. Волошин, Т. С. Мі- щенко, Є. В. Лекомцева // Міжнародний неврологічний журнал. - 2008. - № 3 (7). - С. 9-13.

7. Гуляєв Д. В. Шкали в клінічній неврології / Д. В. ГуляєВ, М. В. Гуляєва. - К. : Видавець Гуляєв Д. В., 2008. - 64 с.

8. Драганова О. В. Фізична реабілітація постінсультних хворих в пізньому відновлювальному періоді / О.В.Драганова, Т. В. Баришок // Педагогіка, психологія та медико-біологічні проблеми фізичного виховання і спорту. - 2009. - № 7. - С. 55-58.

9. Зозуля І. С. Епідеміологія цереброваскулярних захворювань в Україні / І. С. Зозуля, А. І. Зозуля // Український медичний часопис. - 2011. - № 5. - С. 38-41.

10. Кадыков А. С. Реабилитация неврологических больных / А. С. Кадыков, А. А. Черникова, Н. В. Шахпаронова. - М. : МЕДпресс-информ, 2008. - 560 с.

11. Leys D. The main components of stroke unit care / D. Leys, E. Ringelstein, M. Kaste // Cerebrovasc. Dis. - 2007. Vol. 23. - P. 465.

Отримано 25.02.21 